\title{
Forcing Temperature Affects Postproduction Quality, Dark Respiration Rate, and Ethylene Responsiveness of Pelargonium $\times$ domesticum
}

\author{
Kathleen B. Evensen and Karen M. Olson \\ Department of Horticulture, Penn State University, University Park PA 16802 \\ Additional index words. abscission, flowering plants, light compensation point, senescence
}

\begin{abstract}
Postproduction quality, net $\mathrm{C}$ exchange, and petal abscission in response to ethylene were compared following forcing at 21 (day)/16C(night) or $18 / 13 \mathrm{C}(18$-hour photoperiod) of two cultivars of Pelargonium $\times$ domesticum L.H. Bailey. Fewer petals of 2- to 6-day-old florets abscised in response to 60 minutes of $0.7 \mu l$ ethylene/liter on plants forced at low temperature than on plants forced at $3 \mathrm{C}$ higher temperature. Forcing temperature did not affect floret longevity or the number of florets opening during forcing, but the floral display under simulated consumer conditions was prolonged in low-temperature plants by the continued development of buds. Dark respiration rates at 21C were lower in leaves from plants forced at low temperature than in leaves of plants forced at the higher temperature. Differences in postproduction quality between plants forced at high and low temperatures may have been related to the reduced rate of carbohydrate depletion in low-temperature plants.
\end{abstract}

The production environment, including irradiance, temperature, relative humidity, and fertilization, influences the postproduction quality of flowering potted plants (Fjeld, 1986; Harbaugh and Waters, 1982; Nell and Barrett, 1986; Staby and Kofranek, 1979). Unlike for foliage plants, postproduction quality of flowering plants is reduced after low-irradiance acclimatization. Sun-tolerant plants, such as Petunia hybrida Vilm. and Pelargonium $\times$ hortorum, lose flowers and abort buds when placed under low irradiance, and even shade-tolerant plants may not continue to flower, depending on species (Conover and Poole, 1981; Harbaugh and Waters, 1979; Kraszewski and Omrod, 1986). Since flowers are a strong sink for carbohydrates (Ho and Nichols, 1977; Khayat and Zieslin, 1986), the best production conditions for flowering plants are those that promote maximum postproduction carbohydrate availability to support existing flowers and continued bud development.

The major causes of postproduction deterioration of Pelargonium $\times$ domesticum are petal abscission, bud abortion, and failure to continue developing new buds (Deneke et al., 1990; Evensen, 1991; Olson and Evensen, 1990). In addition to cultivar differences in postproduction quality, we have observed that the floral display was exceptionally long-lasting on plants forced with high irradiance and low temperature. However, high irradiance alone [450 vs. $250 \mu \mathrm{mol} \cdot \mathrm{s}^{-1} \cdot \mathrm{m}^{-2}, 21$ (day) $/ 16 \mathrm{C}$ (night)] had no effect on ethylene-induced petal abscission and slightly reduced longevity in the simulated consumer environment (SCE) (Olson and Evensen, 1990). Thus, it appeared that high irradiance was not responsible for the long-lasting floral display.

In this study, we examined the effect of forcing temperature on ethylene sensitivity and postproduction quality of $P . \times d o-$ mesticum, using two cultivars that differ in their postproduction keeping quality, 'Virginia' and 'Majestic' (Olson and Evensen, 1990). Since dark respiration rates and the light compensation points are related to the rate of carbohydrate use of plants in the postproduction environment, we also compared these variables in leaves from plants forced at two temperatures.

\footnotetext{
Received for publication 19 Aug. 1991. Accepted for publication 10 Feb. 1992. The financial support of the American Floral Endowment and the Ohio Floriculture Foundation is gratefully acknowledged. The cost of publishing this paper was defrayed in part by the payment of page charges. Under postal regulations, this paper therefore must be hereby marked advertisement solely to indicate this fact.
}

\section{Materials and Methods}

Plant material. Two genetically related cultivars of $P . \times d o-$ mesticum were chosen for study: 'Virginia', a commercial cultivar, and 'Majestic', a progeny of 'Virginia' $\times$ 'Lavender Grand Slam', previously referred to as 'PSU-1' (Olson and Evensen, 1990). Stock plants, started from culture-virus-indexed cuttings (Oglevee Assocs., Connellsville, Pa.) were maintained in the Penn State horticulture greenhouses. Cuttings harvested from stock plants were recut to $8 \mathrm{~cm}$, dipped in a rooting powder containing 1-napthaleneacetic acid, and rooted in cell packs filled with Metromix 215 (Grace Horticultural Products, Cambridge, Mass.) for 4 weeks in a greenhouse equipped with bottom heat and intermittent mist.

Floral initiation was promoted by exposing rooted cuttings to high irradiance and low temperature for 4 weeks in a controlledenvironment room. An irradiance of $250 \pm 15 \mu \mathrm{mol} \cdot \mathrm{s}^{-1} \cdot \mathrm{m}^{-2}$ for an 18-h photoperiod was provided by metal halide lamps (High Intensity Discharge Super Metalarc 400 R, Sylvania-GTE, Manchester, N.H.). The temperature was maintained at 16(day)/ $11 \mathrm{C}$ (night) $\pm 1 \mathrm{C}$. Plants were fertilized with each subirrigation by use of a solution of $190 \mathrm{mg}$ N/liter made from $15 \mathrm{~N}-7 \mathrm{P}$ 14.1K fertilizer (Peter's Fertilizer Products, Fogelsville, Pa.).

Floral-initiated plants were selected for uniformity and transplanted one per 1.5-liter $(15.2-\mathrm{cm})$ azalea pot in Metromix 350 (Grace Horticultural Products). Pots were randomly placed in one of two controlled-environment growth chambers (Model CEL 5122-27, Sherer/Gillett, Marshall, Mich.) for forcing. The temperature cycles were 21 (day)/16C (night) $\pm 1 \mathrm{C}$ (high) and 18 (day)/13C (night) $\pm 1 \mathrm{C}$ (low). The irradiance was $350 \pm$ $15 \mu \mathrm{mol} \cdot \mathrm{s}^{-1} \cdot \mathrm{m}^{-2}$, provided by cool-white fluorescent and incandescent lamps (Philips Lighting Co., Somerset, N.J., 14\% incandescent on a wattage basis), with an 18-h photoperiod. Plants were fertilized with each drip irrigation with a solution of $250 \mathrm{mg} \mathrm{N} /$ liter using two applications of $15 \mathrm{~N}-7 \mathrm{P}-14.1 \mathrm{~K}$ for every one application of 20N-0P-16.6K fertilizer (Peter's Fertilizer Products). Foliar sprays of insecticidal soap were used before anthesis to control whitefly populations.

Environmental monitoring and instrumentation. Photosynthetic photon flux was measured at midshoot height with a solar monitor equipped with a quantum sensor (Model LI-185B, LICOR, Lincoln, Neb.) at the beginning and end of the growth period in each of the controlled environments (floral initiation, 
forcing, and postproduction). During forcing, irradiance was also measured at 2-week intervals. Air temperatures were measured at midshoot height by maximum-minimum thermometers (Model 5458, Taylor Scientific Consumer Instruments, Arden, N.C.), with an ethanol thermometer calibrated against an NBS standard thermometer, and by recording hygrothermographs (Model 594, Friez/Bendix Co., Baltimore).

Evaluation of ethylene responsiveness. The ethylene responsiveness of randomly selected plants was evaluated $16 \pm 3$ days after first anthesis. Plants were treated with ethylene in darkness at $25 \pm 1 \mathrm{C}$ in a sealed, modified controlled-environment chamber (Model 4005-0, Sherer/Gillett) equipped with four additional fans to improve circulation. Ethylene from source gas of 21 to $25 \mu \mathrm{l} \cdot$ liter $^{-1}$ was added continuously to the chamber to maintain $0.7 \mu \mathrm{l}$ ethylene/liter. Gas samples were taken at 2-min intervals, and ethylene concentration was determined using a Hewlett Packard 5840A gas chromatography equipped with a flame ionization detector and a column of activated alumina. The desired concentration of ethylene was reached within 8 to $14 \mathrm{~min}$ and remained $\pm 0.1 \mu \mathrm{l} \cdot \mathrm{liter}^{-1}$ for the duration of the treatment. Ethylene samples taken at six locations in the chamber indicated that within $10 \mathrm{~min}$ from the start of treatment, the ethylene concentration varied only $\pm 0.05 \mu \mathrm{l} \cdot \mathrm{liter}^{-1}$ within the chamber. To keep ethylene exposure consistent between treatments, the dose of ethylene was determined as parts per billion.hours (ppb.h), the product of concentration and duration in hours (Barden and Hanan, 1972). Ethylene exposure was complete when the total dose reached $700 \mathrm{ppb} \cdot \mathrm{h}$ as determined by 2 -min interval gas sampling. The duration of treatment was 68 $\pm 6 \mathrm{~min}$. Control plants were placed in the chamber for $68 \mathrm{~min}$ with addition of air instead of ethylene.

Petal abscission was evaluated $1 \mathrm{~h}$ after completion of ethylene treatment, since it had been determined in previous experiments that abscission was complete within that time. The percent of florets with $\geq 50 \%$ abscised petals was calculated for each floret age. Two experiments were conducted, with a total of seven plants of each cultivar, temperature, and ethylene treatment.

Evaluation of postproduction longevity. To evaluate duration of floral display, plants that were not treated with ethylene were moved $(16 \pm 3$ days after first anthesis) to a SCE. The SCE was maintained at $50 \% \pm 15 \%$ relative humidity (using a dehumidifier), $21 \pm 1 \mathrm{C}$, with lighting from fluorescent lamps at $32 \pm 5 \mu \mathrm{mol} \cdot \mathrm{s}^{-1} \cdot \mathrm{m}^{-2}$ for $12 \mathrm{~h}$ daily. Constant, uniform moisture was provided to the growing medium by a capillary mat system. Air scrubbers containing $\mathrm{KMnO}_{4}$ (Purafil, Atlanta) were used to prevent ethylene accumulation. Individual floret longevity was determined from the dates of floret anthesis and senescence. Florets were considered senescent if they wilted or if $\geq 50 \%$ of the petals had abscised. The duration of the floral display was defined as the number of days from placement in the SCE until five or fewer healthy florets remained on the plant. Six plants of each cultivar and forcing temperature combination were evaluated in each of two experiments for floret longevity and duration of floral display.

Measurement of net $\mathrm{CO}_{2}$ flux. Net $\mathrm{CO}_{2}$ flux of the youngest fully expanded intact leaves was determined with a LICOR LI6200 Photosynthesis System using a 0.25-liter leaf chamber. Measurements were made at $21 \pm 1 \mathrm{C}$ in the forcing growth chambers at four irradiance levels: $0,15,30$, and $60 \pm 5$ $\mu \mathrm{mol} \cdot \mathrm{s}^{-1} \cdot \mathrm{m}^{-2}$, achieved by using curtains of cheesecloth and black cloth. Plants were held at the test irradiance for at least $2 \mathrm{~h}$ before measurement.
Net $\mathrm{CO}_{2}$ fluxes were determined as the rate of change in $\mathrm{CO}_{2}$ concentration over a 15 -sec interval for a given amount of leaf area. Values were reported as micromoles $\mathrm{CO}_{2}$ per second per square meter. The average leaf area used during measurement was $11 \pm 4 \mathrm{~cm}^{2}$. Four consecutive measurements were obtained per leaf, and two leaves from each of three plants were tested. The mean initial $\mathrm{CO}_{2}$ concentration was $445 \pm 32 \mu \mathrm{l} \cdot \mathrm{liter}^{-1}$.

Statistical analysis. Analysis of variance (ANOVA) and mean separations (Duncan's multiple range test) were conducted using Statistical Anlaysis Systems (SAS Institute, Cary, N.C.) and were considered significant at $P<0.05$. Since there were no significant differences between the two experiments, their data were pooled.

\section{Results}

Floral development and longevity. Plants forced at 21(day)/ 16C (night) flowered 5 to 6 days earlier than plants forced at 18(day)/13C (night) (Table 1). Plants of 'Virginia' reached first anthesis 7 days earlier than plants of 'Majestic' forced at the same temperature. After first flowering, the number of open florets per plant increased steadily to a peak of $\approx 60$ on 'Virginia' and $\approx 50$ on 'Majestic'. The peak floral display (maximum number of open florets per plant) occurred 13 to 15 days after transfer to the SCE in 'Virginia' plants and 6 to 8 days after transfer to the SCE in 'Majestic'.

Forcing temperature did not affect the number of florets per plant that opened during the forcing period (up to the 16th day after first anthesis) (Table 1). However, the number of florets that opened after transfer to the SCE was significantly higher for low-temperature plants of both cultivars. More florets opened during forcing and fewer in the SCE on 'Majestic' than on 'Virginia' (Table 1). Forcing temperature did not affect the number of inflorescences per plant or the number of florets per inflorescence, but 'Virginia' produced about twice as many inflorescences and $\approx 20 \%$ more florets than 'Majestic'.

The floral display on low-temperature plants was significantly longer than on high-temperature plants (Table 2). However, the longevity of individual florets that opened either during forcing or in the SCE did not differ between temperature treatments. Floral display and floret longevity lasted longer for 'Virginia' than for 'Majestic' plants grown at the same temperature, both in the forcing environment and in the SCE.

Individual floret longevity remained constant during the forcing period but declined after transfer to the SCE (data not shown). The mean floret longevity of all florets that opened in the SCE was shorter than the longevity of all florets that opened in the forcing environment (Table 2).

Petal abscission. Petal abscission following ethylene treatment of whole plants increased sharply as florets aged (Fig. 1). Ethylene-induced petal abscission of florets 2 to 6 days old was significantly higher in plants forced at high temperature. Petals on control plants did not abscise during the course of the experiment. There was no significant difference between cultivars in the abscission response.

Net carbon exchange. The dark respiration rate (net $\mathrm{C}$ flux at zero irradiance) of leaves of high-temperature plants was significantly higher (more negative net $\mathrm{CO}_{2}$ exchange) than that of low-temperature plants of both cultivars (Fig. 2). In all treatments, the light compensation point $(\mathrm{LCP}$, net $\mathrm{C}$ exchange $=$ $0)$ was between 15 and $30 \mu \mathrm{mol} \cdot \mathrm{s}^{-1} \cdot \mathrm{m}^{-2}$. There were no obvious differences in vegetative morphology between low- and high-temperature plants.

The increase in net $\mathrm{CO}_{2}$ exchange with increased irradiance 
Table 1. Influence of forcing temperature on floral development. Data shown are means \pm SE.

\begin{tabular}{lcccc}
\hline \hline & $\begin{array}{c}\text { Forcing } \\
\text { temp }\left({ }^{\circ} \mathrm{C}\right) \\
\text { (day/night) }\end{array}$ & $\begin{array}{c}\text { Time } \\
\text { to first } \\
\text { anthesis } \\
\text { (days) }\end{array}$ & $\begin{array}{c}\text { Florets opening } \\
\text { during forcing } \\
\text { (no./plant) }\end{array}$ & $\begin{array}{c}\text { Florets opening } \\
\text { after transfer to SCEz } \\
\text { (no./plant) }\end{array}$ \\
\hline Vultivar & $21 / 16$ & $31.0 \pm 1.2 \mathrm{c}$ & $30.4 \pm 3.1 \mathrm{~b}$ & $61.6 \pm 4.4 \mathrm{~b}$ \\
Majginia & $18 / 13$ & $36.2 \pm 0.1 \mathrm{~b}$ & $28.2 \pm 2.7 \mathrm{~b}$ & $69.1 \pm 6.3 \mathrm{a}$ \\
& $21 / 16$ & $38.2 \pm 0.6 \mathrm{~b}$ & $39.9 \pm 2.4 \mathrm{a}$ & $35.3 \pm 2.6 \mathrm{~d}$ \\
& $18 / 13$ & $43.8 \pm 0.6 \mathrm{a}$ & $39.4 \pm 1.9 \mathrm{a}$ & $43.9 \pm 2.9 \mathrm{c}$ \\
\hline
\end{tabular}

${ }^{\mathrm{z}} \mathrm{SCE}=$ simulated consumer environment.

'Mean separation within columns by Duncan's multiple range test, $P<0.05, \mathrm{~N}=$ 12 plants.

Table 2. Influence of forcing temperature on duration of floral display and floret longevity. Data shown are means \pm SE.

\begin{tabular}{|c|c|c|c|c|}
\hline Cultivar & $\begin{array}{c}\text { Forcing } \\
\text { temp }\left({ }^{\circ} \mathrm{C}\right) \\
\text { (day/night) }\end{array}$ & $\begin{array}{c}\text { Duration of } \\
\text { floral display } \\
\text { in the } \mathrm{SCE}^{\mathrm{z}} \text { (days) }\end{array}$ & $\begin{array}{l}\text { Floret longevity } \\
\text { in the forcing } \\
\text { environment (days) }\end{array}$ & $\begin{array}{c}\text { Floret longevity } \\
\text { in the SCE } \\
\text { (days) }\end{array}$ \\
\hline \multirow[t]{2}{*}{$\overline{\text { Virginia }}$} & $21 / 16$ & $28.2 \pm 1.1 b$ & $18.6 \pm 0.2 \mathrm{a}$ & $17.4 \pm 0.2 \mathrm{a}$ \\
\hline & $18 / 13$ & $33.0 \pm 0.9 a$ & $17.7 \pm 0.2 \mathrm{a}$ & $16.4 \pm 0.2 \mathrm{a}$ \\
\hline \multirow[t]{2}{*}{ Majestic } & $21 / 16$ & $21.2 \pm 0.7 \mathrm{c}$ & $14.2 \pm 0.2 b$ & $12.8 \pm 0.2 b$ \\
\hline & $18 / 13$ & $28.2 \pm 1.2 \mathrm{~b}$ & $13.5 \pm 0.2 b$ & $11.4 \pm 0.2 \mathrm{~b}$ \\
\hline
\end{tabular}

${ }^{\mathrm{z}}$ Duration of floral display was the number of days from placement in the SCE (simulated consumer environment) until five or fewer healthy florets remained on the plant.

${ }^{y}$ Mean separation within columns by Duncan's multiple range test, $P<0.05, \mathrm{~N}=12$ plants.

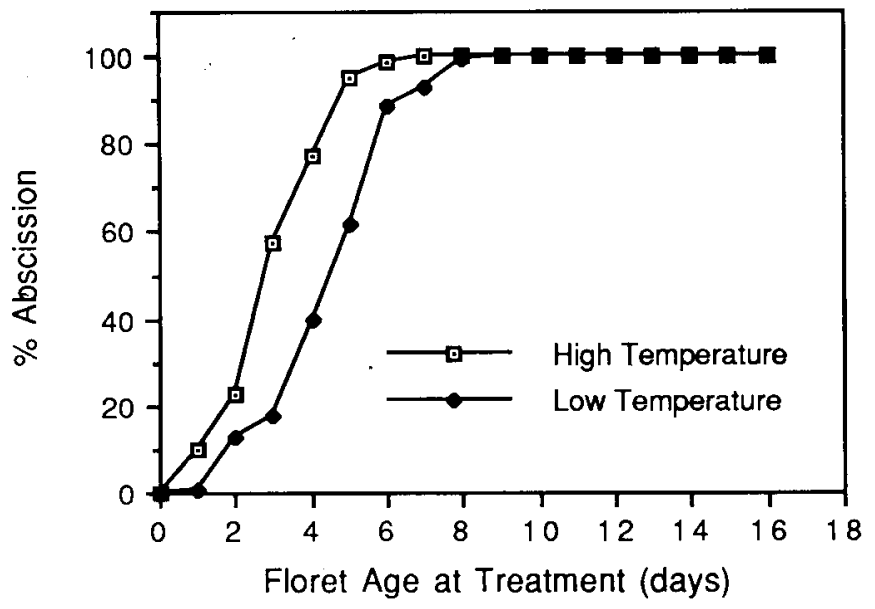

Fig. 1. Percent of florets exhibiting at least $50 \%$ petal abscission following treatment of whole plants with $0.7 \mu$ l ethylene/liter for 68 $\min$ at $25 \mathrm{C}$. There were 14 plants per treatment, each bearing at least 18 florets of each age $\leq 6$ days. Forcing temperature significantly affected ethylene-induced abscission in florets 2 to 6 days old (ANOVA, $P<0.05$ ). Data for the two cultivars were pooled.

did not appear to be linear, especially for 'Majestic' (Fig. 2). This nonlinearity in the vicinity of the LCP ("Kok effect") may be the result of light-induced suppression of respiration (Sharp et al., 1984).

\section{Discussion}

The extent of petal abscission in response to ethylene strongly depended on floret age (Fig. 1; Deneke et al., 1990; Evensen, 1991; Olson and Evensen, 1990). In this paper, we have shown that forcing at low temperature reduces this ethylene responsiveness (Fig. 1). However, this did not account for the superior postproduction quality of low temperature-forced plants, since individual floret longevity was similar between the temperature treatments in the absence of exogenous ethylene (Table 2). During shipping, when exogenous ethylene may be present, plants grown at relatively low temperatures would abscise fewer petals than plants grown at higher temperatures.

The major factor contributing to the prolonged floral display in plants forced at $18 / 13 \mathrm{C}$ was the number of new florets that low temperature-grown plants continued to develop and support. The improved bud development of low-temperature plants was related to metabolic rates. The LCP of all plants was near the irradiance level in the SCE $\left(32 \mu \mathrm{mol} \cdot \mathrm{s}^{-1} \cdot \mathrm{m}^{-2}\right)$. Since the photoperiod in the SCE was $12 \mathrm{~h}$, the daily $\mathrm{C}$ balance of all plants was negative and carbohydrates were continually depleted. Lowtemperature plants exhibited a lower dark respiration rate and, therefore, would metabolize carbohydrate reserves more slowly than high-temperature plants. Decreased production temperature has been associated with increased carbohydrate levels in leaves of P. $\times$ hortorum (White and Warrington, 1984) and poinsettia (Euphorbia pulcherrima Willd. ex K1.) (Senecal et al., 1989). In our study, the low-temperature plants probably had higher carbohydrate reserves at the onset of the postproduction period.

The relationship between metabolic rates and postproduction quality is further supported by comparison of the two cultivars: 'Majestic', which had a higher dark respiration rate than 'Virginia' at both forcing temperatures (Fig. 2), also had a shorter floral display (Table 2). However, the dark respiration rate did not seem to be related to floret longevity, since there were no significant differences in floret longevity between forcing temperatures (Table 2). Longevity of florets that opened in the SCE, which had lower irradiance and a higher mean daily temperature than the forcing environments, was less than that of florets that opened earlier (Table 2). While this relationship could be interpreted as a result of faster carbohydrate depletion in the SCE, it is also possible that the longevity of florets reaching anthesis 

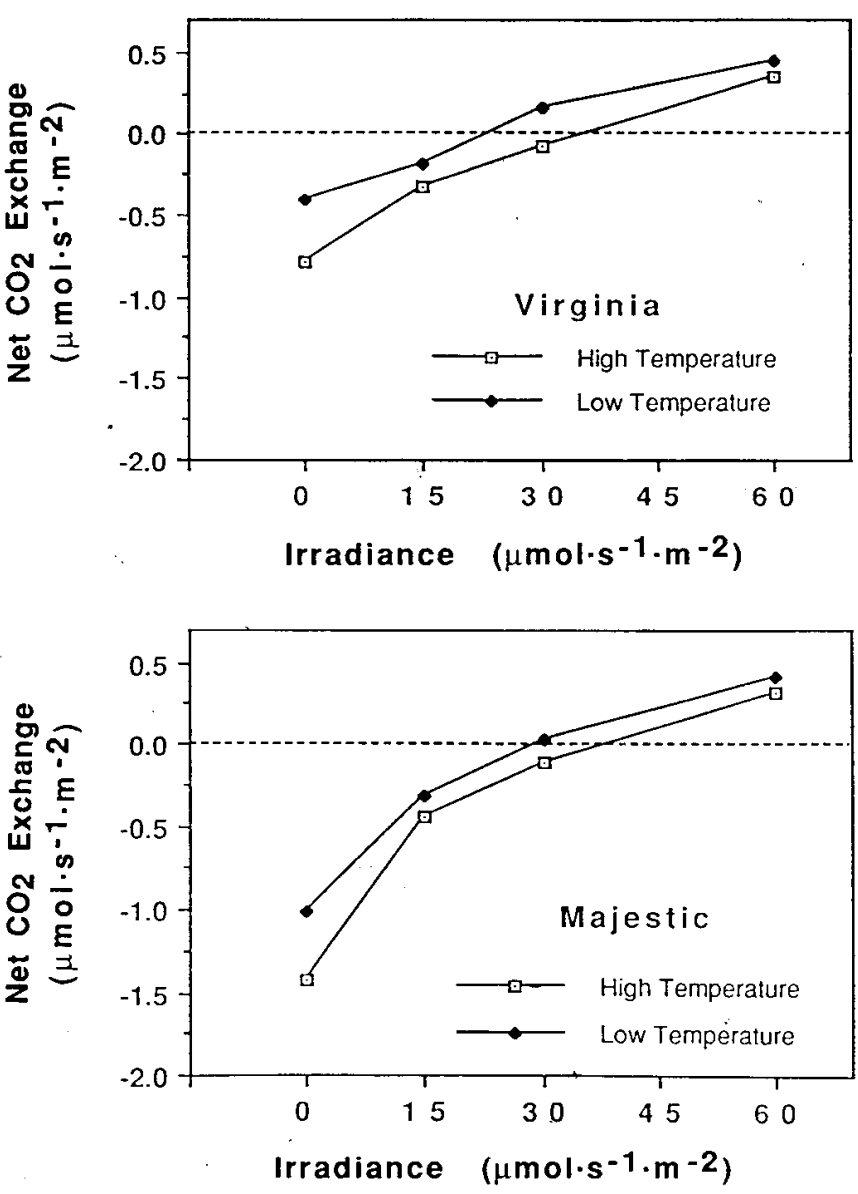

Fig. 2. Net $\mathrm{C}$ exchange at four irradiance levels for two leaves from each of three plants grown at high and low temperatures. The point at which net $\mathrm{CO}_{2}$ exchange $=0$ (dotted line) is the light compensation point. At zero irradiance, cultivar and forcing temperature were significant at $P<0.002$. Between 15 and $60 \mu \mathrm{mol} \cdot \mathrm{s}^{-1} \cdot \mathrm{m}^{-2}$, the ANOVA showed no significant differences in net $\mathrm{C}$ exchange between temperature treatments, and there was a significant difference due to cultivar only at $15 \mu \mathrm{mol} \cdot \mathrm{s}^{-1} \cdot \mathrm{m}^{-2}(P<0.05)$.

late in the flowering cycle would have been shorter, regardless of the environment in which the plants were held. Greater floret longevity, in addition to continued bud development, contributed to the longer floral display in 'Virginia' than in 'Majestic'.

Use of a lower forcing temperature to improve postproduction quality would increase that time to flowering. The disadvantage of delayed flowering with lower production temperatures has been reported for chrysanthemum [Dendranthema grandiflorum (Ramat.) Kitamura] (Bonaminio and Larson, 1980; Parups, 1978), petunia (Bonaminio and Larson, 1980), rose (Rosa $\times$ hybrida) (Moe, 1972; Zieslin et al., 1987), P. $\times$ hortorum (Armitage et al., 1981; White and Barrington, 1984) and P. $\times$ domesticum (Powell and Bunt, 1978). In this study, we obtained significantly better postproduction quality of $P . \times$ domesticum with a $3 \mathrm{C}$ (day and night) lower temperature. Since initial flowering was delayed only 4 to 6 days and the number of florets per plant was not significantly affected during the forcing period, the advantage of improved postproduction quality would, we believe, compensate for the slight delay in flowering.

\section{Literature Cited}

Armitage, A.M., W.H. Carlson, and J.A. Flore. 1981. The effect of temperature and quantum flux density on the morphology, physiology, and flowering of hybrid geraniums. J. Amer. Soc. Hort. Sci. 106:643-647.

Barden, L.E. and J.J. Hanan. 1972. Effect of ethylene on carnation keeping life. J. Amer. Soc. Hort. Sci. 97:785-788.

Bonaminio, V.P. and R.A. Larson. 1980. Influence of reduced night temperature on growth and flowering of 'May Shoesmith' chrysanthemums. J. Amer. Soc. Hort. Sci. 105:9-11.

Conover, C.A. and R.T. Poole. 1981. Influence of light and fertilizer levels and fertilizer sources on foliage plants maintained under interior environments for one year. J. Amer. Soc. Hort. Sci. 106:571574 .

Deneke, C.F., K.B. Evensen, and R. Craig. 1990. Regulation of petal abscission of Pelargonium $\times$ domesticum. HortScience 25:937-940.

Evensen, K.E. 1991. Ethylene responsiveness changes in Pelargonium $\times$ domesticum florets. Physiol. Plant. 82:409-412.

Fjeld, T. 1986. The effect of relative humidity, light intensity and temperature on keeping quality of Begonia $\times$ cheimantha Everett; Acta Hort. 181:251-255.

Harbaugh, B.K. and W.E. Waters. 1979. Evaluation of flowering potted plants under simulated home conditions. HortScience 14:743745.

Harbaugh, B.K. and W.E. Waters. 1982. Influence of controlled-release fertilizer on Exacum affine Balf. F. 'Elfin' during production and subsequent simulated home condition. HortScience 17:605-606.

Ho, L.C. and R. Nichols. 1977. Translocation of ${ }^{14} \mathrm{C}$ sucrose in relation to changes in carbohydrate content in rose corollas cut at different stages of development. Ann. Bot. 41:227-242.

Khayat, E. and N. Zieslin. 1986. Effect of different night temperature regimes on the assimilation, transport and metabolism of carbon in rose plants. Physiol. Plant. 67:608-613.

Kraszewski, R.A. and D.P. Ormrod. 1986. Utilization of a response surface technique to study light acclimation of indoor flowering plants. J. Amer. Soc. Hort. Sci. 111:47-55.

Moe, R. 1972. Effects of daylength, light intensity and temperature on growth and flowering in roses. J. Amer. Soc. Hort. Sci. 97:796800.

Nell, T.A. and J.E. Barrett. 1986. Production light level effects on light compensation point, carbon exchange rate and post-production longevity of poinsettias. Acta Hort. 181:257-262.

Olson, K.M. and K.B. Evensen. 1990. The influence of irradiance on ethylene sensitivity and postproduction quality of Pelargonium $\times$ domesticum. Acta Hort. 272:341-346.

Parups, E.V. 1978. Chrysanthemum growth at cool night temperature. J. Amer. Soc. Hort. Sci. 103:839-842.

Powell, M.C. and A.C. Bunt. 1978. The effect of temperature and light on flower development in Pelargonium $\times$ domesticum. Scientia Hort. 8:75-79.

Senecal, M., B. Dansereau, and R. Paquin. 1989. Fertilization and night temperature effects on growth and carbohydrate status of poinsettia. Can. J. Plant Sci. 69:347-349.

Sharp, R.E., M.A. Matthews, and J.S. Boyer. 1984. Kok effect and the quantum yield of photosynthesis. Plant Physiol. 75:95-101.

Staby, G.L. and A.M. Kofranek. 1979. Production conditions as they affect harvest and postharvest characteristics of poinsettias. J. Amer. Soc. Hort. Sci. 104:88-92.

White, J.M. and I.J. Warrington. 1984. Effects of split-night temperatures, light, and chlormequat on growth and carbohydrate status of Pelargonium $\times$ hortorum. J. Amer. Soc. Hort. Sci. 109:458-463.

Zieslin, N., E. Khayat, and Y. Mor. 1987. The response of rose plants to different night temperature regimes. J. Amer. Soc. Hort. Sci. 112:86-89. 